\section{THE CAUSES OF DECLINE OF HOG DEER (AXIS PORCINUS) IN PROTECTED AREAS OF HIMALAYAN WEST BENGAL}

\author{
M.K. Bhowmik \\ Centre for Wildlife, West Bengal Animal and Fishery Sciences, \\ Belgachia, Kolkata, West Bengal 700037, India.
}

The Hog Deer (Axis porcinus), commonly known as 'Para' in India, is listed as a 'Lower Risk near threatened' in the 2000 Red List of Threatened Species (Hilton-Taylor, 2000) and in the Indian Mammal Conservation Assessment and Management Plan (Molur et al., 1998). The species exists in certain South and South-east Asian countries including India where it is sparsely distributed in the diverse and mosaic vegetation covers of certain protected areas along the Himalayan foothills of northern and eastern India (Prater, 1998). In Himalayan West Bengal, small populations of the animal survive only in Jaldapara Wildlife Sanctuary and Gorumara National Park (Bhowmik, 2000). However, the factors contributing for the decline of species are unknown due to scant scientific investigation carried out in the region. The present study was therefore, undertaken to identify the causes of decline of Hog Deer, which in turn, helps in formulating conservation plans to protect the species in the Protected Areas of the region.

The present study was conducted in Jaldapara Wildlife Sanctuary $(216.00 \mathrm{~km})$ and Gorumara National Park $(79.45 \mathrm{~km})$, two home ranges of Hog Deer in sub-Himalayan West Bengal between June, 1998 and May, 1999. The two PAs are located in the flood plains of three main rivers viz. Torsa, Jaldhaka and Murti, and nine rivulets within the civil district of Jalpaiguri, West Bengal.The forest types consist of dry-wet-mixed, riverine, sal and evergreen forests and savannah grasslands. They belong to biogeographacial zone 7b (Lower Gangetic Plains) having geological formations of alluvial, tarai and bhabar soils. The climate is tropical with distinct summer, monsoon and winter. The maximum is $10^{\circ} \mathrm{C}$ in January, average rain fall is about $380 \mathrm{~cm}$ with high humidity (75\%-95\%). Winter is dry and sunny.

This study was based on the findings of a detailed survey that indicated the distribution of Hog Deer and its habitats on dense grassland vegetation covers as well as grassland with woodland successions of $6\left(96.04 \mathrm{~km}^{2}\right)$ and two $\left(6.5 \mathrm{~km}^{2}\right)$ blocks of Jaldapara Wildlife Sanctuary and Gorumara National Park respectively
(Bhowmik \& Chakraborty, 1999; Bhowmik et al., 1999). The concerned blocks were demarcated into different compartments to facilitate carrying out the study regarding factors contributing to the decline of Hog Deer in Protected Area. These blocks and their concerned compartments were monitored on elephant back, jeep and foot on a network arrangement between June, 1998 and May, 1999.

Data concerning factors causing shrinkage of habitats (colonization of clibmers, weeds and ferns; natural process of successions and wood plantation) were critically evaluated by direct observations. Climbers and weeds, grown profusely on the vegetation covers of open grassland habitat were collected and identified by a plant taxonomist, Department of Botany, University of Kalyani. In addition, information with respect to catastrophes (flood, cyclone and drought), threats (hunting and diseases), risks (wild fire, inbreeding depression, intra-species fighting,predation and polution/ poisoning hazards) and other limiting fators were obtained directly or indirectely from forest staff and fringe villagers.

A good number of factors for the viability of Hog Deer were identified. These included:

\section{Shrinkage of habitat (logging)}

Weeds: The prolific growth of various weeds on the vegatation cover of savannah and riverine grasslands poses a serious problem for the survival of the animal. The most common weeds were Leea indica, L. macrophylla, L. sambuciana and L. asiatica which spread like carpet, hampering the growth of fodder plants usually consumed by the animal. In addtion, Lantana camara, Cassia tora, Solanum nigrum, Clerodendron bengalensis, Ageratum conizoides and Eupatorium doratum were also observed to suppress the growth of floral species. Prolific growth of certain ferns sometimes surpassed the growth of forage plants.

Climbers: Michenia cordata and M. scandens, two highly prolific climbers, were identified as the grasses of savannah grasslands in the two protected areas. Other climbers were Smilax sp. and Bauhinia vahlii. All these climbers had a potential to damage the habitat of Hog Deer.

Livestock grazing: There are 32 villages in the fringes of Jaldapara Wildlife Sanctuary containing 68,500 livestock heads. Likewise, 12 villages lie on the fringes of Gorumara National Park with 10,000 heads of livestock. During the survey, quite a large numbers of livestock animals, mainly the cattle from the fringe villages of two protected areas were found grazing in the grassland between $0700 \mathrm{hr}$ and $1600 \mathrm{hr}$. Livestock grazing was more pronounced during summer months when there was competition for fodder between the wild herbivores and domestic cattle and buffaloes in the study area. Livestock grazing, not only limits the availability of food for Hog Deer and other wild herbivores, but also possibly expose the Hog Deer population 
to the risk of livestock-borne diseases.

Existence of other wildlife in the same habitat: Apart from Hog Deer, savannah and riverine grasland vegetation also provide grazing ground for One-horned Rhinoceros (Rhinoceros unicornis), Gaur (Bos gaurus), Asiatic Elephant (Elephas maximus), Chital (Axis axis), Sambar (Cervus unicolor) and Barking Deer (Muntiacus muntjak). The small areas of grassland cover, as well as the existence of other wildlife in the same habitats indicate severe restriction of grazing fields, which in turn limits the Hog Deer population in the protected areas.

Other factors of habitat loss: It was also observed that Hog Deer habitat has dwindled due to natural process of succession e.g. grasslands being colonized by woodlands, and also plantations of Teak and Jarul trees. Such natural process of succesion results in conversion of grasslands into woodlands, which essentially reduce the usable habitat of Hog Deer. In addition, cutting of thatch and Kesia grasses by fringe villagers in the savannah grassland also effect the habitat of species considerably. Grassland habitat destruction therefore, is a serious threat to the survival of many species of wildlife including Hog Deer.

\section{Catastrophes}

Flood and erosion of rivers and rivulets: Flood, a natural disaster, was found common in almost every year in the two protected areas. The Torsa and five rivulets passing through the Jaldapara Wildlife Sanctuary swell heavity and large grassland covers become inundated. Severe flood during July 1993 and 1996, not only caused severe damage to grassland habtats, but also washed away many small animals including Hog Deer in Jaldapara Wildlife Sanctuary. Likewise, grasslands of Gorumara National Park were also badly affected by flood.

Erosion of river and rivulelts are of serious concern to the riverine grasslands, mainly inhabited by small and large herbivores in the two protected areas. Bank erosion of Torsa River and five rivulets pose a threat to the riverine grassland habitats of Jaldapara Wildlife Sanctuary. Similarly, a considerable erosion problem also exists in Jaldhaka and Murti rivers of Gorumara National Park.

The drought and cyclonic damage to a limited extent are almost an annual phenomenon in Jaldapara Wildlife Sanctuary.

\section{Threats}

Hunting: Few incidences of hunting of Hog Deer was recorded in Jaldapara Wildlife Sanctuary during November-February, 1998. Enquiry revealed that tea garden labourers usually indulged in deer hunting throughout the year. Hunting of deer was also reported as a tradition of tribals of fringe villages during festivals.
Diseases: Hog Deer was found susceptible to various infectious, parasitic and non-infectious diseases. Of a total of 174 recorded diseases (Bhowmik, 2000), tuberculosis, pneumonia, colibacillosis and still-births are considered highly fatal, and perhaps responsible for decline of species in the protected areas today. It is believed that certain infectious and parasitic diseases are likely to be transmitted from livestock animals that graze in the grassland habitats of the protected areas utilising the common grazing fields of Hog Deer and other wild herbivores.

\section{Risk}

Inbreeding depression: As the different herds of Hog Deer in the protected areas were closed, inbreeding was expected to be quite common. Due to deliterious effect of genes in an inbred population, various deformities and breeding effects are sure to be expected. In Gorumara National Park, a progeny with leg deformity was identified. In the populations, poor sex-drive and poor-libido were not uncommon.

Wild fire: Occurence of wild-fire was observed in both the protected areas under study. When the grass covers and fallen tree leaves dried in winter or post-winter season, the cattle graziers, women-folk collecting fire wood, hunters and collector of non-timber forest produce (NTEF) set fire to vegetation cover. According to Lahan and Sonowal (1973) and Dhungel and O'Gara (1991), the annual burning of grasslands in Asian forests is an ancient practice. But wildfires might have the following impacts:

a. suppression of destruction in the growth of natural floral species in the grassland habitats,

b. destruction of microflora leading to loss of soil moisture,

c. changes in the vegetation compostition due to loss of soil moisture,

d. increment of soil erosion due to soil desecration, and

e. increase the incidences of hunting because of better visibility.

Intraspecies fighting: This factor was considered quite common among the breeding stags and male yearlings because of dominance over females or dominance for territory. In this study, intraspecies fighting was recorded in male populations during the breeding season (September-October) in two protected areas. Tuberculous and debiliated animals also had a higher mortality.

Predation: In the present investigation, no predation was identified. However, information gathered from the forest staff indicated that predation by large cats was not frequent.

Chemical poisoning: Deaths due to poisonous chemical were observed in four Hog Deer in Jaldapara Wildlife Sanctuary, being confirmed by postmortem examination. As a routine practise, various chemicals/pesticides/ fungicides are used in the tea gardens and agricultural fields adjacent to protected areas. Such 
hazardous chemicals are sometimes ingested by the ungulates while grazing. Further, with light showers these chemicals are washed out and accumulated in ditches, low-land areas and shallow streams, and animals are affected while drinking such contaminated water.

\section{Other limiting factors}

Human interference: Jaldapara Wildlife Sanctuary being surrounded by 32 villages and having settlements inside the conservation unit, is subjected to maximum human interference thus affecting biodiversity conservation in this "protected area". Human interference was identified as both direct and indirect, including collections of timber, fire wood and NTFP, boulder, bamboo and grass cutting, cattle grazing, hunting and fishing.

Gorumara National Park is surrounded by 12 villages with considerable human populations. Investigations revealed that there was a lower degree of biotic pressure on the forest resources of this National Park because of local people involvement in biodiversity conservation programs.

Tourism: Tourists and visitors were found to visit both the protected areas round the year, except during the rainy season. Most of the tourists roamed in the forest covers on elephant back or by vehicles, wich upset the natural movement and grazing of wild herbivores. Presence of tourists almost daily in Jaldapara Wildlife Sanctuary also were found to damage the vegetation and tend to change wild animal behaviour.

Results clearly suggested that multiple factors are held responsible for the decline of Hog Deer in two protected areas of Himalayan West Bengal. However, the factors reported in this study, would definitely help to formulate conservation strategies of the species in the region.

\section{Acknowledgement}

Financial support in the form of Mid-Career Fellowship awarded by the World Wildlife Fund - US, to the author is gratefully acknowledged. The help of the staff of the Department of Forests, Govt. of West Bengal is highly appreciated. Heart felt thanks to the Taxonomist, Department of Botany, University of Kalyani for identification of weeds and climbers of the protected areas

\section{References}

Bhowmik, M.K. and T. Chakraborty (1999). Status and distribution of Hog Deer (Axis porcinus) in Protected Areas of sub-Himalayan West Bengal. Zoos' Print Journal 1-14: 151-152.

Bhowmik, M.K., T. Chakraborty and A.K. Raha (1999). The habitat and food habits of Hog-deer (Axis porcinus) in protected areas of sbuHimalayan West Bengal. Tiger Paper 26: 25-27.

Bhowmik, M.K. (2000). Disease spectrum and fawn mortality of hog deer (Axis porcinus) in Eastern Himalayan region. Tiger Paper 27:1720.

Dhungel, S.K. and B.W. O' Gara (1991). Ecology of the Hog Deer in Royal Chitwan National Park, Nepal. Wildlife Monographs 119: 1-40.

Hilton-Taylor, C. (Compiler) (2000). 2000 IUCN Red List of Threatened Species. IUCN, Gland, Switzerland and Cambridge, UK, xviii+61pp+cd-rom.

Lahan, P. and R.N. Sonowal (1973). Kaziranga Wildlife Sanctuary, Assam: a brief description and report on the census of large animals. Journal of the Bombay Natural History Society 70: 245-278.

Molur, S., P.O. Nameer and S. Walker (Editors) (1998). Report of the workshop "Conservation Assessment and Management Plan for Mammals of India" (BCPP Endangered Species Project), Zoo Outreach Organisation, Conservation Breeding Specialist Group, India, Coimbatore, 176pp.

Prater, S.H. (1998). Text Book of Indian Animals. $11^{\text {th }}$ edition, pp. 291-292. Oxford University Press, Delhi. 